\title{
ИССЛЕДОВАНИЕ СОЕДИНЕНИЙ, ЭКСКРЕТИРУЕМЫХ БАКТЕРИАЛЬНОЙ КЛЕТКОЙ, ПОД ВОЗДЕЙСТВИЕМ ПРОИЗВОДНОГО ГЕМИНА
}

\section{С.В. Благодаров ${ }^{1}$, Г.А. Желтухина', К.В. Сидорук², М.И. Семашко',}

B.Е. Небольсин ${ }^{3}$

${ }^{1}$ Институт тонких химических технологий им. М.В. Ломоносова, МИРЭА - Российский технологический университет, 119454, г. Москва, просп. Вернадского, д. 86

2НИЦ «Курчатовский институт» - ГосНИИгенетика»,

117545, Москва, 1-й Дорожный проезд, д. 1.

${ }^{3} 000$ «ФАРМИНТЕРПРАЙСЕЗ» 121205, г. Москва, территория инновационного центра «Сколково», Большой бульвар, д. 42, строение 1

DOI: 10.19163/MedChemRussia2021-2021-454

E-mail: laboratory211@yandex.ru

Цель работы: исследование выхода АТФ из бактериальных клеток под действием синтетического аргининсодержащего производного гемина (ПГ).

Методика. K резистентным штаммам E. faecalis ATCC 29212, B.subtilis PxyLA_ABxen и S.aureus ATCC 25923 добавляли аргининсодержащее ПГ при минимальной подавляющей концентрации. Каждые 5 минут отбирали 100 мкл культуральной жидкости (КЖ) и помещали в кювету для люминометра. В последнюю добавляли люциферин и люциферазу, помещали в люминометр и измеряли уровень люминесценции.

Результаты. Аргининсодержащее ПГ в концентрации, соответствующей минимальной подавляющей концентрации, взаимодействует с бактериальной мембраной, вызывая быстрое вытекание АТФ из клетки бактерии. Максимальный уровень АТФ в бактериальной среде наблюдается через 30-50 минут в зависимости от штамма бактерии, при этом максимальный уровень АТФ был 2,5-20 раз выше, чем в контроле. Полученные данные могут указывать на то, что важной частью механизма антибактериального действия ПГ является его взаимодействие с бактериальной мембраной, которое вызывает вытекание АТФ из бактериальной клетки.

Вывод. Продемонстрировано, что производные гемина способны взаимодействовать бактериальной мембраной, вызывая вытекание АТФ из клетки. 